\title{
KARAKTERISASI MORFOLOGI TANAMAN ENAU DI KENAGARIAN SUNGAI NANIANG
}

\author{
Trisia Wulantika \\ Jurusan Budidaya Tanaman Pangan, Politeknik Pertanian Negeri Payakumbuh \\ Email : wulan_trisia@ymail.com
}

Diterima: 15 Agustus 2020

Disetujui: 22 September 2020

\begin{abstract}
Enau plant (Arenga pinnata Merr) is a type of palma plant that the entire plant can be utilized and potential to be developed. Sungai Naniang is the highest sugar producer in Bukik Barisan SubDistrict, with an area of 20 ha. This research aims to find out the morphological characteristics of germplasm enau in Kenagarian Sungai Naniang. This research has been carried out in May to June 2018 with purposive sampling method. The results of the study found 4 variations of the stem color of the entire accession namely dark brown, light brown, grayish brown and grayish brown. The leaves of the enau plant are complete and compound leaves.Based on observations that have been made, there are not many variations in qualitative characters, otherwise many variations are found in quantitative characters. on the entire accession is black with a rough surface. Male flowers are like bullets, they sit in pairs and are purple. Round Female Flower, stand alone, green. Seeds are round in oval shape The number of seeds 3 per fruit and white.
\end{abstract}

Keywords : Enau, Characterization, Morphology, Plant Breeding

\begin{abstract}
ABSTRAK
Tanaman enau (Arenga pinnata Merr) adalah salah satu jenis tumbuhan palma yang Keseluruhan bagian tanamannya dapat dimanfaatkan dan potensial untuk dikembangkan. Kenagarian Sungai Naniang merupakan penghasil gula enau tertinggi di Kecamatan Bukik Barisan, dengan luasan mencapai 20 Ha. Penelitian ini bertujuan untuk mengetahui karakteristik morfologi plasma nutfah enau di Kenagarian Sungai Naniang.Penelitian ini telah dilaksanakan pada bulan Mei sampai Juni 2018 dengan metode purposive sampling. Hasil penelitian ditemukan 4 variasi warna batang dari keseluruhan aksesi yaitu berwarna cokelat gelap, cokelat terang, coklat keabu-abuan dan abuabu.Daun tanaman enau merupakan daun lengkap dan majemuk.Berdasarkan pengamatan yang telah dilakukan, tidak banyak ditemukan variasi pada karakter kualitatif, sebaliknya banyak ditemukan variasi pada karakter kuantitatif. ijuk pada keseluruhan aksesi berwarna hitam dengan permukaan yang kasar. Bunga Jantan seperti peluru, duduknya berpasangan dan berwarna ungu. Bunga betina bulat, berdiri sendiri, berwarna hijau. Biji berbentuk bulat lonjong Jumlah biji 3 perbuah dan berwarna putih.
\end{abstract}

Kata Kunci : Enau, Karakterisasi, Morfologi, Pemuliaan Tanaman

\section{PENDAHULUAN}

Pohon enau adalah salah satu jenis tumbuhan palma yang memproduksi buah, nira dan pati atau tepung di dalam batang. Hasil produksi aren ini semuanya dapat dimanfaatkan dan memiliki nilai ekonomi (Lempang, 2012). Tanaman enau sangat berpotensi untuk dikembangkan. Hampir seluruh bagian tanaman enau dapat dimanfaatkan.
Daun dimanfaatkan untuk atap rumah atau gubuk, biji muda dimanfaatkan untuk kolang-kaling sebagai campuran makanan atau minuman. Batang tanaman enau yang sudah tua dapat diambil tepungnya untuk pembuatan tepung enau. Akar enau dapat digunakan untuk vas bunga, keranjang buah dan lain-lain. Ijuk enau dapat dimanfaatkan untuk pembuatan sapu, sikat dan tali. Penyadapan tandan bunga jantan menghasilkan nira yang 
dapat dijadikan gula, minuman, cuka, alkohol, dan bahan baku etanol untuk mendukung kebutuhan bioenergi.

Plasma nutfah merupakan sumber daya alam keempat selain sumber daya air, tanah dan udara yang penting untuk dilestarikan. Dalam bidang pertanian, plasma nutfah banyak dikaji dan dikoleksi dalam rangka meningkatkan produk pertanian dan penyediaan pangan karena plasma nutfah merupakan sumber gen yang berguna bagi perbaikan tanaman baik gen untuk ketahanan terhadap penyakit, hama, gulma dan ketahanan terhadap cekaman lingkungan abiotik. Selain itu plasma nutfah juga merupakan sumber gen yang dapat dimanfaatkan untuk peningkatan kualitas hasil tanaman (Sari 2013).

Wulantika (2017) dalam penelitian terhadap analisis variabilitas fenotipik enau di Kecamatan Bukik Barisan melaporkan bahwa Kenagarian Sungai Naniang merupakan penghasil gula enau tertinggi. Oleh karena itu kegiatan karakterisasi tanaman enau perlu dilakukan.

Kegiatan identifikasi dan deskripsi tanaman diharapkan dapat memberikan informasi keunggulan dari suatu plasma nutfah berdasarkan ciri-ciri khusus yang dimiliki oleh plasma nutfah tersebut (Litbang Pertanian 2004)

Dengan adanya penelitian ini dapat diketahui karakteristik morfologi plasma nutfah enau di Kenagarian Sungai Naniang, Kecamatan Bukik Barisan, Kabupaten Limapuluh Kota sehingga dapat memberikan informasi dasar bagi pemulia tanaman dalam kegiatan pemuliaan tanaman enau dimasa yang akan datang.

\section{METODE}

\section{Lokasi Penelitian}

Penelitian ini dilaksanakan di Kenagarian Sungai Naniang, Kecamatan Bukik Barisan, Kabupaten Limapuluh Kota, pada bulan Mei sampai Juni 2018.

\section{Bahan dan Alat}

Bahan yang digunakan dalam penelitian ini adalah plasma nutfah enau (Arenga pinnata) yang telah memasuki fase generatif, aquades, dan kuisioner. Alat yang digunakan adalah mistar, meteran, kantong plastik, kamera digital, GPS (global position system), refraktrometer, kertas label, tangga, pisau, parang, colour chart, smart measure, jangka, jangka sorong dan alatalat tulis.

\section{Metode Penelitian}

Metode yang digunakan adalah survey dengan pengambilan sampel secara sengaja (Purpossive Sampling). Jumlah sampel yang diambil ditiap Jorong (Desa) adalah 10 aksesi, Jorong yang dipilih sebagai lokasi penelitian adalah Jorong Kampung Baru, Apar dan Batu Balabuah I.

Jumlah sampel yang diambil sebanyak 30 aksesi, di lokasi dengan ketinggian beragam. Kriteria sampel adalah tanaman yang sudah memasuki fase generatif dan berumur lebih dari 8 tahun.

Pengambilan data dan pengamatan dilakukan secara langsung terhadap tanaman enau, serta pengisian bahan kuisioner, dan wawancara dengan petani enau di lokasi pengambilan sampel.

\section{HASIL DAN PEMBAHASAN}

\section{Morfologi Batang Tanaman Enau}

Batang adalah salah satu bagian penting yang merupakan tempat penyimpanan dan penumpukan hasil fotosintesis berupa asimilat (tepung). Sehingga dari batang ini dapat diambil tepung enau yang digunakan sebagai bahan pangan dan pakan ternak.

Tanaman enau di Kenagarian Sungai Naniang memiliki permukaan batang yang memperlihatkan ada bekas pelepah dikeseluruan aksesi yang diamati. Karakter warna kulit batang, ditemukan 4 variasi warna dari keseluruhan aksesi yaitu ada yang berwarna cokelat gelap, cokelat terang, 
coklat keabu-abuan dan abu-abu, dari ketiga jorong pada umumnya aksesi yang diamati berwarna cokelat terang.

Terjadinya variasi tersebut adalah sehubungan dengan karakter kuantitatif. Hal ini dapat dipahami bahwa karakter kuantitaif adalah karakter yang dikendalikan oleh beberapa gen minor dan lebih banyak dipengaruhi oleh faktor lingkungan (Ferita et al.2015)

Rata-rata lingkaran batang di Batu Balabuah I 1,337 meter, 1,423 meter di Apar dan 1,547 meter di Kampung Baru. Rata-rata tinggi enau di Batu Balabuah I 8,8 meter, Apar 10,8 meter, dan 12,93 meter di Kampung Baru. 30 aksesi yang diamati berumur besar dari 10 tahun, umur diketahui dari wawancara langsung dengan petani penyadap nira disetiap aksesi yang diamati. Penampilan warna kulit batang tanaman enau dapat dilihat pada Gambar 1.
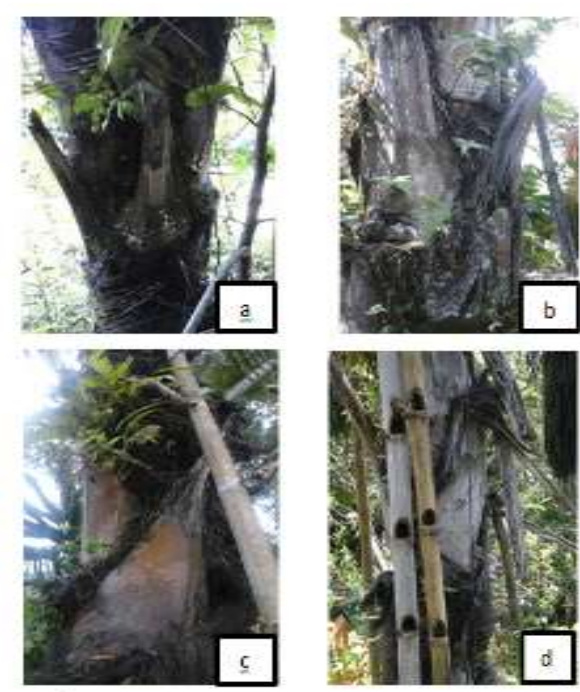

Gambar 1.Penampilan warna kulit batang enau

Keterangan :

a.Berwarna cokelat gelap pada aksesi Batu Balabuah 1 (BB4)

b. Berwarna cokelat keabu-abuan pada aksesi Kampung Baru (KP5)

c.Berwarna cokelat terang pada aksesi Apar (AP2)

d. Berwarna abu-abu pada aksesi Batu Balabuah 1 (BB1)

\section{Morfologi Daun Tanaman Enau}

Daun tanaman enau merupakan daun lengkap dan majemuk. Menurut Tjitrosoepomo (2003) daun lengkap adalah daun yang mempunyai pelepah daun (Vagina), tangkai daun (Petiolus) dan helaian daun (Lamina). Berdasarkan pengamatan yang telah dilakukan, tidak banyak ditemukan variasi pada karakter kualitatif, sebaliknya banyak ditemukan variasi pada karakter kuantitatif.

Selanjutnya ditemui panjang pelepah yang berbeda pada setiap aksesi, rata-rata panjang pelepah di jorong Batu Balabuah 1 adalah 1,002 meter, 0,895 meter di jorong Apar dan 0,877 di jorong Kampung Baru. Panjang pelepah terpendek ditemui pada aksesi KP2 (Kampung Baru 2) 0,57 meter dan pelepah terpanjang ditemui pada aksesi (Batu Balabuah1 8) BB8 1,2 meter.

Karakter panjang rachis tergolong pada kategori sangat pendek sampai sedang, kisaran nilainya 3-7,24 meter, rata-rata panjang rachis untuk jorong Batu Balabuah 1 yaitu 4,928 meter, Apar 6,666 m dan Kampung baru 6,336 meter.

Karakter panjang tangkai daun juga ditemui nilai yang berbeda pada setiap aksesi, nilainya berkisar antara 3,3-7,35 meter. Rata-rata panjang tangkai daun di jorong Batu Balabuah 1 5,139 meter, Apar 6,853 meter dan Kampung Baru 6,548 meter.

Rata-rata jumlah anak daun pada jorong Batu Balabuah 1 189,7 helai dan ini termasuk dalam kategori sedikit, pada jorong Apar 275,4 helai, ini termasuk dalam kategori banyak dan pada jorong Kampung Baru termasuk kategori sedang dengan helaian sebanyak 249,6 helai.

Rata-rata panjang anak daun di jorong Batu Balabuah 1 1,416 meter, 1,587 meter di jorong Apar dan 1,561 meter di jorong Kampung Baru.

Rata-rata lebar anak daun di jorong Batu Balabuah $15,913 \mathrm{~cm}$, Apar $7,242 \mathrm{~cm}$ dan Kampung Baru 7,216 cm. Hal ini sesuai dengan Irawan et al. (2009) bahwa tanaman enau memiliki 
lebar anak daun antara $5,93 \mathrm{~cm}-8,50 \mathrm{~cm}$. Karakter morfologi daun dapat dilihat pada Gambar 2.
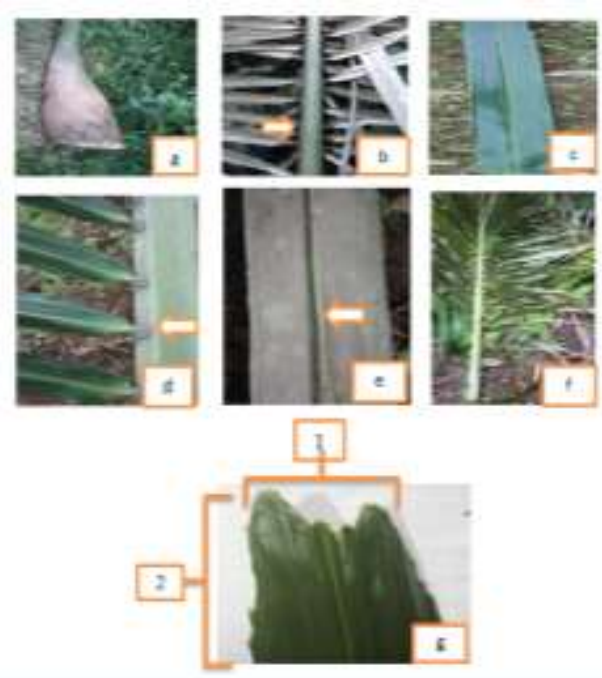

Gambar 2. Pengamatan Karakter Morfologi Daun Tanaman Enau Keterangan :
a. Bentuk pelepah enau bersegi dan berwarna hijau

b. Bentuk tangkai enau bersegi dan berwarna hijau

c. Bangun anak daun berbentuk pita, permukaan licin mengkilat

d. pangkal anak daun yang meruncing

e. Pertulangan anak daun sejajar

f. Tata letak anak daun berhadapan bersilang

g. Ujung anak daun yang terbelah (1), tepi anak daun bergerigi (2)

\section{Ijuk Tanaman Enau}

Ijuk menyelubungi batang pohon enau, ijuk dihasilkan dari pohon enau yang telah berumur lebih dari 5 tahun. Pohon yang masih muda produksi ijuknya kecil, demikian pula, pohon yang mulai berbunga kualitas dan hasil ijuknya tidak baik. Ijuk pada hasil pengamatan keseluruhan aksesi berwarna hitam dengan permukaan yang kasar. Warna ijuk dapat dilihat pada Gambar 3
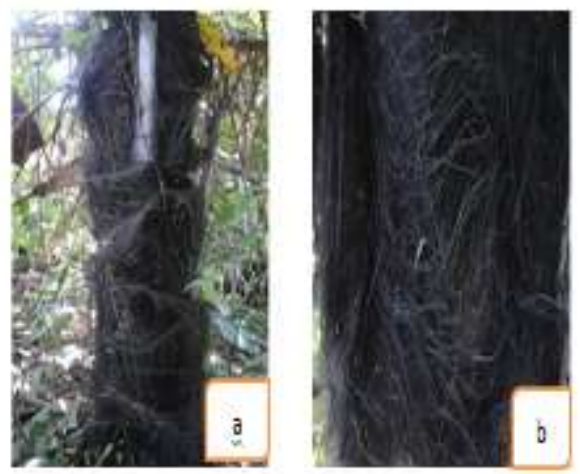

Gambar 3. Warna Ijuk Tanaman Enau Keterangan :
a. Ijuk berwarna hitam yang melekat di batang
b. Ijuk enau berwarna hitam

\section{Bunga Jantan dan Betina Tanaman Enau \\ Pada penelitian ini, pengamatan} terhadap bunga enau meliputi tata letak bunga, susunan bunga, bentuk bunga jantan dan betina, komponen bunga jantan dan betina, masa reseptif bunga jantan dan betina dan warna bunga jantan dan betina.

Pada saat penelitian, bunga yang banyak ditemui di lapangan adalah bunga jantan, untuk bunga betina hanya ditemui pada aksesi AP9 dan AP4. Data pengamatan bunga jantan dan betina enau dapat dilihat pada Tabel 1. 
Tabel 1.Pengamatan Bunga Jantan Dan Betina Tanaman Enau

\begin{tabular}{|c|c|c|c|c|}
\hline Bunga & Bentuk & Warna & Susunan/Bagian & Masa Reseptif \\
\hline $\begin{array}{l}\text { Bunga } \\
\text { Jantan }\end{array}$ & $\begin{array}{l}\text { Seperti peluru, } \\
\text { duduknya berpasangan } \\
\text { (Gambar } 4 \mathrm{~b} .)\end{array}$ & Ungu & $\begin{array}{c}\text { Daun bunga, } \\
\text { benang } \\
\text { sari, kelopak } \\
\text { bunga, kepala sari } \\
\text { berbentuk jarum } \\
\text { (Gambar 4d.) }\end{array}$ & $\begin{array}{l}\text { Pada bunga jantan } \\
\text { inisiasi awal hingga } \\
\text { anther siap untuk } \\
\text { menyerbuki bunga } \\
\text { betina adalah } \\
\text { selama } 51-58 \text { hari }\end{array}$ \\
\hline $\begin{array}{l}\text { Bunga } \\
\text { Betina }\end{array}$ & $\begin{array}{l}\text { Bulat, berdiri sendiri } \\
\text { (Gambar 5) }\end{array}$ & Hijau & $\begin{array}{l}\text { Putik, mahkota, } \\
\text { kelopak }\end{array}$ & $\begin{array}{c}\text { Inisiasi awal } \\
\text { pembentukan } \\
\text { bunga betina hingga } \\
\text { siap untuk diserbuki } \\
\text { adalah berkisar } \\
60-65 \text { hari }\end{array}$ \\
\hline
\end{tabular}

Berdasarkan Tabel 1. Bunga jantan berbentuk seperti peluru, duduknya berpasangan, kelopaknya berwarna hijau, hingga hijau keunguan, terletak berentengan dalam satu tandan, jumlahnya hingga ratusan bunga, didalamnya terdapat puluhan tangkai benang sari yang akan tersebar keluar ketika bunga enau jantan mekar. Benang sari inilah yang akan beterbangan menyerbuki bunga betina.
Proses penyerbukan pada bunga enau dibantu oleh angin dan serangga. Bunga jantan yang telah mekar, secara perlahan rontok dan jatuh di bawah pohon enau, menandai proses penyerbukan sudah terjadi.

Tandan bunga jantan inilah yang sering disadap untuk diambil niranya karena bisa menghasilkan nira yang lebih banyak dibandingkan tandan bunga betina. Pengamatan terhadap bunga jantan enau dapat dilihat pada Gambar 4

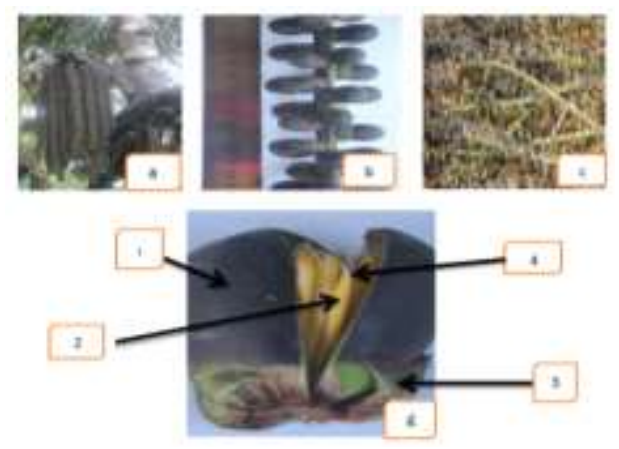

Gambar 4.Bunga jantan tanaman enau

Keterangan :

a. Satu tandan bunga jantan

b. Bunga jantan yang berbentuk peluru dan berwarna ungu

c. Bunga jantan yang telah mekar dan rontok

d. Bagian bunga jantan : daun bunga(1), benang sari(2), kelopak bunga(3), kepala sari berbentuk jarum(4)

Selanjutnya pengamatan terhadap bunga betina enau dapat dilihat pada Gambar 5. Bunga betina berbentuk bulat, berdiri sendiri, berwarna hijau. Bakal buah beruang tiga, dengan tiga kepala putik.
Bunga enau berbentuk tandan dengan malai bunga yang menggantung. Bunga tersebut tumbuh pada ketiakketiak pelepah atau ruas-ruas batang bekas tempat tumbuh pelepah.

Proses pembentukan bunga mula-mula muncul dari pucuk, 
kemudian disusul oleh tunas-tunas berikutnya ke arah bawah pohon.

Bunga enau tumbuh secara basiferal, yaitu bunga yang paling awal terletak di ujung batang, sedangkan bunga yang tumbuh belakangan terletak pada tunas berikutnya ke arah bawah.

Tandan bunga yang ada di bagian atas terdiri dari bunga betina, sedangkan yang di bagian bawah, biasanya terdiri dari bunga jantan.

Jadi pada satu pohon enau terdapat bunga jantan dan bunga betina, hanya saja berada pada tandan yang berbeda. Karena letaknya ini, maka bunga enau termasuk kelompok monoceus uniseksual.

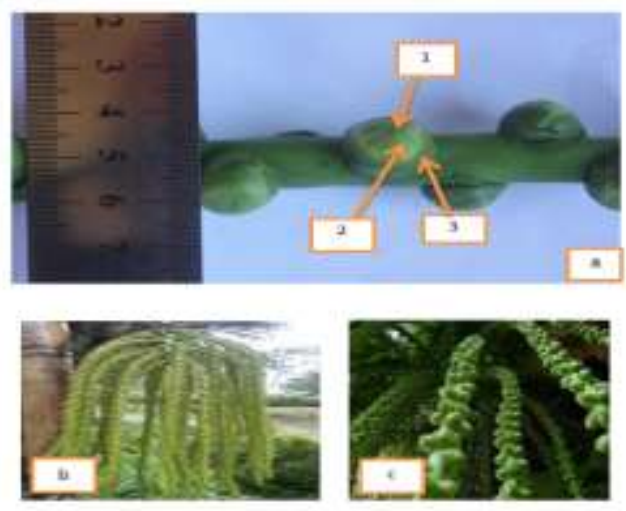

Gambar 5. Bunga Betina Enau

Keterangan :

a. Putik (1), Mahkota (2), Kelopak bunga (3)

b. Satu tandan bunga betina

c. Untaian bunga betina

Pada umunya tanaman enau mulai membentuk bunga pada umur 1216 tahun. Bunga yang muncul pertama kali adalah bunga betina, sekitar 3 bulan kemudian bunga jantan mulai tumbuh di bawah bunga betina.

Penelitian terdahulu yang telah dilakukan oleh Guntur (2012) mengenai fenologi bunga enau, menyatakan bahwa lama pembungaan dan pembuahan pada enau sejak awal inisiasi sampai buah masak berkisar 89126 hari, masak bunga jantan dan betina tidak sama.

Inisiasi awal pembentukan bunga betina hingga siap untuk diserbuki adalah berkisar 60-65 hari. Pada bunga jantan inisiasi awal hingga anther siap untuk menyerbuki bunga betina adalah selama 51-58 hari.

Jika penyerbukan sudah terjadi maka kelopak bunga betina akan rontok dan berjatuhan ke tanah, yang tertinggal dalam untaian adalah bakal buah. Bakal buah inilah yang kemudian berkembang menjadi buah enau. Tidak semua bunga betina dapat berkembang menjadi buah enau. Hanya bunga yang berhasil mengalami penyerbukan yang bakal buahnya dapat berkembang menjadi buah enau.

\section{Buah dan Biji Tanaman Enau}

Karakter buah yang diamati adalah jumlah tandan buah per tanaman, jumlah untaian buah per tanaman, bentuk buah, diameter buah dan bobot perbuah.

Karakter biji, yang diamati adalah bentuk biji, diameter biji, jumlah biji perbuah, warna biji muda dan bobot perbiji.

rata-rata jumlah tandan buah pertanaman di jorong Batu Balabuah I 3,8 , jorong Apar 4,2, jorong Kampuang Baru 3,3.

Rata-rata jumlah untaian buah pertanaman 31,2 di Batu Balabuah I, 31,8 di Apar dan 28,9 di Kampuang Baru. Termasuk buah buni, penampangnya berbentuk bulat.

Rata- rata diameter buah di Batu Balabuah I 50,12 mm, 51,43 mm di Apar dan 48,06 mm di Kampuang Baru. 
Rata-rata bobot perbuah di Batu Balabuah I 24,09 gram, 26,39 gram di Apar dan 22,43 gram di Kampuang Baru.

Menurut Widyawati (2012) adanya perbedaan bobot perbuah dikarenakan tingkat kematangan buah yang berbeda dan juga struktur perikarp masing-masing buah yang berbeda. Tandan buah dan bentuk buah enau dapat dilihat pada Gambar 6

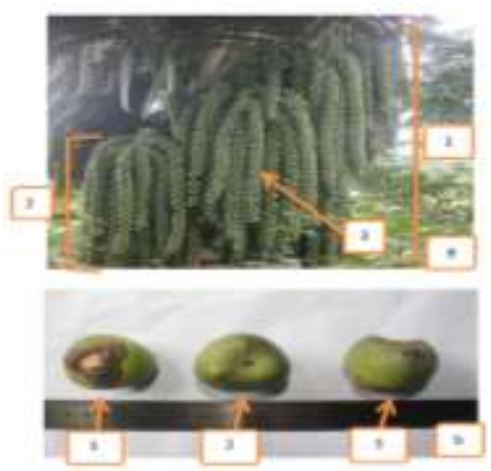

Gambar 6.Tandan Buah Dan Bentuk Buah Tanaman Enau Keterangan :

a. Tandan buah enau pada pohon (1), satu tandan buah enau (2), satu untaian buah enau (3)

b. Buah enau yang berbentuk bulat :Tampak atas(1),Tampak bawah(2),Tampak samping(3) Gambar 7.

Pengamatan terhadap struktur buah dan bentuk biji enau dapat dilihat pada

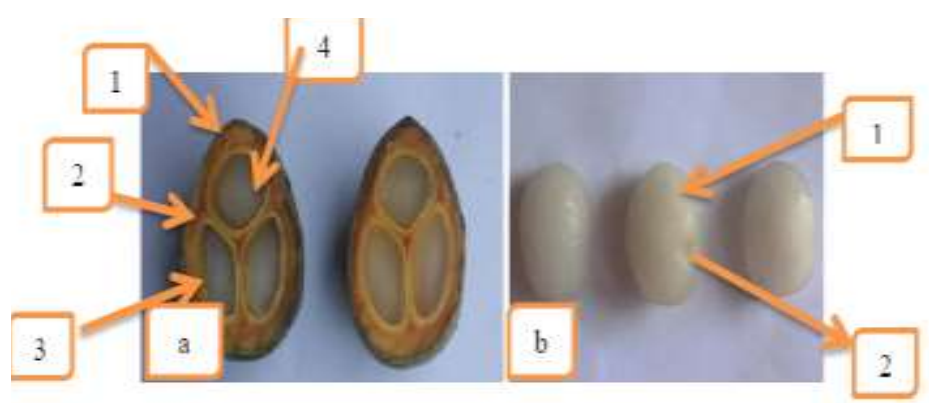

Gambar 7.Struktur buah, bentuk dan warna biji enau Keterangan :

a. Eksokarp(1), mesokarp(2), seedcoat(3), endosperm(4)

b. Bentuk biji bulat lonjong berwarna putih. Endosperm(1), Embryo(2)

Di lapangan untuk semua aksesi ditemui biji berbentuk bulat lonjong dengan diameter rata-rata $22,65 \mathrm{~mm}$ pada jorong Batu Balabuah 1, 23,19 mm pada jorong Apar dan 21,65 mm pada jorong Kampung Baru. Jumlah dan warna biji muda perbuah untuk semua aksesi adalah 3 dan berwarna putih. Bobot perbiji ditemui nilai yang berbeda disetiap aksesi. Rata-rata bobot perbiji di jorong Batu Balabuah I 11,77 gram, 12,44 gram di Apar dan 11,31 gram di Kampung Baru. Pada Gambar 7, buah enau terdiri atas Eksokarp, mesokarp, endokarp, dan endosperm. Bagian-bagian dari buah enau terdiri dari :

1. Kulit luar, halus dan berwarna hijau pada waktu masih muda dan menjadi kuning setelah tua (masak)

2. Daging buah, berwarna putih kekuning-kuningan

3. Kulit biji, berwarna kuning dan tipis pada waktu masih muda 
dan berwarna hitam yang keras setelah buah masak

4. Endosperm, berbentuk lonjong agak pipih berwarna putih agak bening dan lunak pada waktu buah masih muda dan berwarna putih, padat atau agak keras pada waktu buah sudah masak, dapat dilihat pada Gambar 7.

\section{KESIMPULAN}

Ditemukan 4 variasi warna batang dari keseluruhan aksesi yaitu berwarna cokelat gelap, cokelat terang, coklat keabuabuan dan abu-abu.

Daun tanaman enau merupakan daun lengkap dan majemuk.Berdasarkan pengamatan yang telah dilakukan, tidak banyak ditemukan variasi pada karakter kualitatif, sebaliknya banyak ditemukan variasi pada karakter kuantitatif. Ijuk pada keseluruhan aksesi berwarna hitam dengan permukaan yang kasar.

Bunga Jantan seperti peluru, duduknya berpasangan dan berwarna ungu. Bunga Betina Bulat, berdiri sendiri, berwarna hijau. Biji tanaman enau berbentuk bulat lonjong Jumlah biji 3 perbuah dan berwarna putih.

\section{DAFTAR PUSTAKA}

Ferita I, Tawarati, Syarif Z. 2015. Identifikasi Dan Karakterisasi Tanaman Enau (Arenga Pinnata) Di Kabupaten Gayo Lues. Pros Sem Nas Masy Biodiv Indon Volume 1, Nomor 1, Maret 2015 Halaman: 31-37

Guntur, G.2012. Fenologi Perkembangan Bunga Tanaman Enau. \{Skripsi\}. Padang. Fakultas Pertanian. Universitas Andalas

Irawan. Rahmayani. Iskandar. 2009 Studi Variasi Pemanfaatan Pengolahan dan Pengelolaan Enau Desa Rancakalong. Kecamatan Rancakalong, Kabupaten Sumedang, Jawa Barat.

Disampaikan pada Seminar Nasional Etnobotanu IV, Cibinong 18 Mei 2009.
Lempang,M.2012.Pohon Aren Dan Manfaat Produksinya. Info Teknis EBONI Vol.9 No.1, Oktober 2012 : 37-54

Litbang Pertanian. 2004. Pelestarian plasma nutfah sudah mendesak. Badan Litbang Pertanian. Kementerian Pertanian. Jakarta.

Sari DI. 2013. Pentingnya plasma nutfah dan upaya pelestariannya. Pengawas Benih Tanaman Ahli Pertama BBPPTP Surabaya.

Tjitrosoepomo, G. 2003. Morfologi Tumbuhan. Gadjah Mada University Press. Yogyakarta. 268 Hal.

Widyawati N, 2012. Sukses Investasi Masa Depan dengan bertanam Pohon Aren. Lily Publisher. Yogyakarta. 104 Hal.

Wulantika, T.2017. Keragaman Fenotipe Aren (Arenga Pinnata) Di Kecamatan Bukit Barisan Kabupaten Lima Puluh Kota.Jurnal Ilmiah Pertanian, Vol. 15, No 2, Pebruari 2019 